\section{Protection of the Aborigines of Australia}

The series of three articles by Dr. Donald F. Thomson, reciting his experiences among the aborigines of Arnhem Land, which appeared in The Times of July 5-7, will have been followed with close attention by all who desire a wider application of scientific methods in the approach to the problems arising out of the contacts of Westem civilization and peoples of backward culture. A preliminary account of Dr. Thomson's work appeared earlier and was noted in NATURE of January 8 (p. 68). Dr. Thomson, as he himself expresses it, was 'loaned' by the University of Melbourne to the Government of the Commonwealth of Australia to visit, establish friendly relations, and make an anthropological survey of the native tribes, who had been responsible for unrest and trouble in Arnhem Land in 1933. His expedition, as is now well known and as he records, was completely successful in getting into touch with tribes reputed unapproachable, and as a result of his investigations lasting over the two years $1935-37$, he was able to present to the Federal Government a report in which he, as an anthropologist, suggested certain measures to be taken if this interesting and, in their way, attractive people were to be saved from degradation and extinction. That extinction is their inevitable fate, unless immediate steps for their protection are taken, is patent from Dr. Thomson's alarming discovery that the number of aborigines in these tribes has fallen lower by far than was thought. Further, he was able to point to the grave injury which is being inflicted on the aborigines by wellmeaning but mistaken philanthropy. A people who had established an equilibrium in the technique of existence in a country of difficult conditions are abandoning their traditional mode of life to obtain the inadequate benefits of a weekly ration and a few of the cast-off rags of civilization, to their irretrievable detriment.

Dr. Thomson suggests as the immediate need of the situation the complete segregation of the aborigines on an inviolable reserve. The aboriginal reserves are in theory already 'out of bounds' for the white population, but in practice this has not been observed. $\mathrm{He}$ is also of the opinion that control of all aborigines should be handed over by the State Govermments to the single control of the Federal Government. Dr. Thomson was able recently to explain his suggestions in fuller detail than was possible in The Times before the Committee on Applied Anthropology of the Royal Anthropological Institute (as reported in Man of July). After analysing the causes of depopulation and alluding to the failure of missionary effort to turn the tribesmen into gardeners, he went on to suggest that the policy of complete segregation should be supplemented by a legal code adapted to native conceptions, the creation of a special nativeaffairs service staffed by anthropologists, working as mobile patrols, and additional medical service. Further, that the system of segregation should be maintained until a constructive development policy has been worked out for those aborigines who are already detribalized.

\section{An Expedition to North Rona}

A small expedition left the Summer Isles by Fishery Cruiser Vigilant for North Rona on July 11. Dr. and Mrs. F. Fraser Darling of Tanera expect to spend six months studying the social behaviour and environmental influences on behaviour of the Atlantic or Grey seal, Halichcerus gryphus. Dr. Fraser Darling has already published researches on the social life found in the red deer and in several species of birds. His work on the Grey seal began with a four months expedition to the Treshnish Isles in 1937. The gregariousness apparent in these seals is of patriarchal type and entirely different from the matriarchy of the deer herds and the communities of pairs which constitute breeding flocks of birds. Dr. Fraser Darling's expedition is a private venture, but the cost is being defrayed in part by a fellowship from the Carnegie Trust and grants-in-aid from the Royal Society, the British Association, the Institute for the Study of Animal Behaviour and the Challenger Society. The Fishery Board for Scotland has cooperated generously in the all-important matter of transport. North Rona lies fifty miles north-east of the Butt of Lewis and is a rock-bound islet of less than half a square mile in area. The Atlantic seal repairs there to breed in large numbers from September to November, and the island is also one of the few breeding places of that interesting nocturnal bird, Leach's fork-tailed petrel.

\section{Engineers and International Affairs}

IN his address to the North East Coast Institution of Engineers and Shipbuilders, when he received the diploma of honorary fellowship of the Institution on June 24, Rear-Admiral G. H. Rock, of the Constructive Branch of the United States Navy, made special reference to the education of engineers and the participation of engineering organizations in international affairs. In educational circles in the United States, there has been an astonishing increase in the interest in such matters. All the leading nations, he said, are exporters and importers of education in its various forms. There are about 8,500 foreign students in the colleges and universities in the United States and an even larger number of American students are studying abroad. In the academic year 1936-37, 204 American professors were either studying or teaching in foreign universities, while at the same time in American colleges and universities there were 175 foreign professors. No professions are more concerned with international activities than those of shipbuilding and ship operation, and he suggested that institutions such as the North-East Coast Institution should lend encouragement to the improvement in the education of naval architects and marine engineers, encourage successful professional men to assist actively in teaching, make more suitable arrangements for ensuring young engineers more reasonable opportunity for employment, and arrange for a more general exchange of students between Great Britain and the United States. Admiral Rock recalled that he received a part of his education in 1890-92 at the University of Glasgow, and he was then sometimes bewildered by 
leading articles in the Glasgow Herald which criticized the enrolment of foreign students in naval architecture and marine engineering. International cooperation, however, he considers, offers more of gain than of loss, in fact, "gain for all, with loss to none".

\section{The Zeppelin Centenary}

$\mathrm{Bx}$ the issue of commemorative stamps, the opening of a museum at Friedrichshafen, and in other ways, Germany has been paying homage to the memory of Count Ferdinand Zeppelin, of airship fame, the centenary of whose birth occurred on July 8. Born on the shores of Lake Constance, Count Zeppelin was educated at Stuttgart, and at twenty years of age became an infantry officer. His military studies led him to visit Italy, France and England, and in 1863 he served with the Union forces in the American Civil War, in the course of his service making a balloon ascent. Returning home, he took part in the war between Prussia and Austria and in the Franco-Prussian War and afterwards rose to high command. In 1891 he retired as a general. $\mathrm{He}$ had long conceived the idea of aerial navigation by airship, and free from official duties, and possessing considerable means, he devoted all his energies to the construction of a rigid airship. In 1900 he achieved his first success with $Z 1$, a craft $420 \mathrm{ft}$. long and $38 \frac{1}{2} \mathrm{ft}$. in diameter, the envelope of which contained seventeen gasbags with a total capacity of about $400,000 \mathrm{cub}$. $\mathrm{ft}$. of hydrogen. The two cars suspended beneath the ship had two 18 horse-power Daimler engines. On July 2, 1900, the airship was hauled out of its floating shed on Lake Constance and covered a distance of $3 \frac{1}{2}$ miles before being landed on the water and towed back to the shed. As a military officer, Zeppelin had visualized the use of airships for observations and for carrying dispatches, but their use as a means of transport was his chief aim, and one of his ambitions was to see Europe and America connected by an airship service. This, however, he did not live to see, for he died in Berlin on March 8, 1917, in the midst of the Great War.

\section{Auguste Forel and Alcoholism}

IN a paper on Auguste Forel and his campaign against alcoholism, read before the Society for the Study of Inebriety and Drug Addiction on July 12, Dr. J. D. Rolleston, after a short sketch of Forel's life, stated that though an active campaign against alcoholism had previously been carried out for many years in Great Britain and the United States, Forel was a pioneer in the scientific anti-alcoholic movement not only in Switzerland, his fatherland, but also on the continent of Europe. The lack of recognition of his work in Great Britain was attributed by Dr. Rolleston to two reasons. In the first place, Forel was strongly opposed to making the campaign against alcoholism inseparable from religion and Christianity in particular, as it is in this country and the United States. The second reason was the severe blow to Anglo-Saxon prudery and obscurantism caused by his classical work on the sexual question. On the other hand, the high appreciation of his work in foreign countries was shown by quotation of the opinions of eminent neurologists, psychiatrists and others in Germany, Hungary, Switzerland and the United States. Forel's contributions to the study of the alcohol problem were then considered under the headings of blastophthoria, alcoholism and the sexual question, exposure of popular errors concerning alcohol, such as the view that beer and wine do not cause alcoholism and the value of alcohol as a food, drug, and indispensable agent in sociability, alcohol and sport, and the treatment of alcoholism.

\section{Inland Water Survey}

DEFINITE quantitative results of the Inland Water Survey Committee's investigations are forthcoming in the Surface Water Year-Book of Great Britain 1935-36 (London: His Majesty's Stationery Office, $5 s$. net) which is a statistical report (issued by the Ministry of Health and the Scottish Office) relating to the inland water resources of Great Britain during the twelve months ended September 30, 1936. The publication provides detailed information about the surface water. resources of a dozen drainage basins, together with their rainfall. Results for underground water are being published separately in a different form. Twenty-seven rivers, at twenty-eight gauging stations, have been the subject of continuous measurement and the results are tabulated in regard to daily maximum and minimum water levels and daily mean discharge in cusecs. The Year-Book furnishes, moreover, in each case a brief description of the station and the drainage area, together with monthly evaluations of rainfall. The issue of this publication, which is to be continued annually, marks a further stage in the development of the Survey and it will be welcomed by all the various bodies who are interested in the use and application of water whether for agricultural purposes, or for land drainage, fisheries, industries, navigation, sewage disposal or water supplies and the like. Some useful conversion tables are included.

\section{The Norman Lockyer Observatory}

THE annual report of the Norman Lockyer Observatory, Sidmouth, shows that the activities of the Observatory are well maintained. The 12-in. McClean telescope has been used for taking spectra of $\zeta$ Aurigæ during its 1937 eclipse and also of Finsler's comet and of $A$-type stars. Its chief work has been in preparation for colour-temperature observations on early-type stars, and the preliminary experiments have shown that colour-temperature observations may be profitably taken up with this instrument. The 9-in. Kensington telescope has been used on a selected number of bright-line stars, with special attention to $\gamma$ Cassiopeiæ. Some photographs of star fields have been taken with the Zeiss triplet camera attached to the instrument. Three meteor cameras fixed outside the dome have been used for the photography of meteors, but unfortunately with. out success up to the present. Prof. Blumbach has used the Mond equatorial for photographs of galactic clusters, Finsler's Comet, and some test plates of the 